\title{
Impact of the Serbian Banking Regulatory Framework Development on the Economic Growth of Serbia
}

Article history:

Received 12 November 2012

Sent for revision 01 March 2013

Received in revised form 26 March 2013

Accepted 26 March 2013

Available online 15 April 2013

\begin{abstract}
The dynamic relationship between the banking regulatory framework and Basel capital standards, on the one side and economic growth and other macroeconomic indicators on the other side, attracts international academic and business circles for many years. Perceived from the Serbian perspective, the impact of the banking regulation development, or the Basel standards application, on economic growth is one of the most actual issues, especially since Serbia starting from December 31st 2011, began the Basel II application. The fact that the National Bank of Serbia and the Serbian commercial banks, gradually directed attention to more actual Basel III standard, further increasing the importance of the topic that this paper will be addressed. Quantitative and qualitative analyzes that were performed during the research presented in this paper indicate a significant potential for further positive effects, including economic growth, due to the implementation of Basel standards in Serbia. Positive results of application largely depend on adequate preparation, analysis and actions of all relevant parties in Basel standards implementation.
\end{abstract}

Keywords: Banking, Basel Capital Standards, Economic Growth, Regulatory Policy, Risk Management

Rezime: Dinamičan odnos regulatornog okvira bankarskog poslovanja, odnosno Bazelskih standarda o kapitalu, s jedne strana i pokazatelja ekonomskog rasta i drugih makroekonomskih indikatora s druge strane, zaokuplja pažnju svetskih akademskih i poslovnih krugova već duži niz godina. Gledano iz ugla Srbije, uticaj razvoja bankarske regulative, odnosno primene Bazelskih sta-

\footnotetext{
${ }^{1}$ Nenad Milojević, Hypo Alpe-Adria-Bank a.d. Belgrade, nenad.m.milojevic@gmail.com

${ }^{2}$ Prof. dr Bojan Dimitrijević, University Educons
} 
Milojević, Dimitrijević: Impact of the Serbian Banking Regulatory Framework...

ndarda na ekonomski rast je jedno od veoma aktuelnih pitanja, posebno jer je Srbija počev od 31.12.2011. godine, započela primenu Bazel II standarda. Činjenica da Narodna banka Srbije i poslovne banke u Srbiji, postepeno usmeravaju pažnju i ka sve aktuelnijem Bazel III standardu, dodatno povećava značaj teme kojoj će u ovom radu biti posvećena pažnja. Kvantitativne i kvalitativne analize koje su urađene tokom istraživanja predstavljenog u ovom radu, ukazuju na značajan potencijal za ostvarivanje daljih pozitivnih efekata, između ostalog, i na ekonomski rast, usled primene Bazelskih standarda $u$ Srbiji. Pozitivni rezultati primene u mnogome zavise od adekvatne pripreme, analize i poteza svih relevantnih strana u procesu primene Bazelskih standarda.

Ključne reči: bankarstvo, Bazelski standardi o kapitalu, ekonomski rast, regulatorna politika, upravljanje rizicima

\section{Introduction}

Correlation between regulatory policy, banking and economic growth is a topic that has become in recent world economic science especially topical by the Basel capital standards introduction. Over the past two and half decades, the macroeconomic consequences of the Basel capital standards implementation, i.e. Basel I, Basel II in particular, and now Basel III standards, have been analyzed by many experts (primarily from the EU and the U.S., but also by developing countries' experts). Bearing in mind that, in terms of the Serbian banking business regulatory framework, from December 31, 2011 we stepped into a new era of regulatory policy - Basel II era, it is necessary, among other things, that Basel II implementation research aspects are directed to determining the possible macroeconomic consequences of implementation of Basel II in Serbia, especially regarding impact on country's economic growth.

Micro and macro regulatory policy implementation effects, i.e. Basel standards are inextricably related and have a dynamic relationship. Connection between micro and macro effects of the capital regulatory framework and its dynamic relationship directly or indirectly permeates all aspects of the economy and society. The effects of the Basel standards application, such as changes in the level of banks capital adequacy ratio (CAR), the impact on implementation costs and the impact on the banks' business and many other micro effects, represent some of the most important issues of the microeconomic impact of the Basel standards application. Regarding macroeconomic effects (closely connected with micro effects), the general effect of the Basel II provisions and other Basel standards on the financial system stability, is a very important issue. In addition, the macroeconomic effects associated with the Basel standards implementation are: the impact on economic growth, interest rates, the impact on macroeconomic indicators, procyclicality, the 
Milojević, Dimitrijević: Impact of the Serbian Banking Regulatory Framework...

capital allocation, the availability of funds for various social and business segments.

In this paper, we analyze different aspects of micro and macro regulatory framework impact, but we primarily have in mind the Basel standards impact on economic growth in Serbia, especially since this issue, in terms of quantitative and qualitative scientific research is relatively new in Serbia. Conclusions regarding these topics can be very valuable for the further Basel standards implementation in Serbia. Especially in terms of the tendency to maximize the effects on the micro and macro level, as well as the sense of aspiration that eventually identified hazards, be promptly observed and to avoid possible negative consequences.

Taking into consider disadvantages of the Basel Accord from the year 1988 (Basel I), Basel Committee on Banking Supervision (BCBS) has initially reacted with amendments, and then with adopting Basel II standards (2004), followed by a number of amendments to Basel II. After the start of the crisis, Basel II critics have been specially actualized, and in addition to the micro effects, Basel II macroeconomic impact (particularly impact on economic growth) has become one of the major points of the Basel II implementation positive and negative effects analysis.

After numerous critics of certain provisions of Basel II, in 2009 the regulation changes followed as well as the new regulatory documents adoption, the application of which is yet to come. Further revision, regulatory changes, consultations of the relevant institutions are continuing at an accelerated pace. According to this, over the next years implementation of the significantly revised and more demanding regulatory framework (Basel III) compared to the current one, will begin.

In Serbia, following the Basel I implementation, implementation of an improved and significantly more demanding regulatory framework began - Basel II (at the end of 2011). Also, the National Bank of Serbia and commercial banks in Serbia are analyzing Basel III. Given the above, it is necessary to carefully consider all the relevant consequences of further implementation of the Basel standards in Serbia, which imply a strong influence on the micro and macro levels. In this paper, we will specifically give the attention to the effects of the Basel standards application on economic growth of Serbia, as one of the most important macroeconomic phenomena. 


\section{Banking Business Regulatory Framework Development in the World and its Foundation on the Basel Standards}

Starting from the eighties of the twentieth century, BCBS capital standards, in a decisive way have been influencing the creation of the regulatory framework, capital and risk management in the banking industry. From 1988 Basel I standard (together with its amendments) encountered a wide applications and has manage to contribute to financial stability increase and strengthening of the risk and capital management worldwide.

$$
\frac{\text { Total Capital }}{\text { RWA (credit risk) }}=\text { Capital adequacy ratio } \geq 8 \%
$$

At the beginning this regulatory framework was focused on the treatment of credit risk, as the most significant risk in the modern world banking, and later it took into account the market risk. It was implemented in more than 100 countries and has set the foundation for modern capital and risk management in the world. However, the simplified Basel I regulatory framework has shown some weaknesses. That is the reason why it had to be modified and replaced by Basel II, in order to meet the challenges of a new financial era.

$$
\frac{\text { Total Capital }}{\text { RWA (credit and market risk) }}=\text { Capital adequacy ratio } \geq 8 \%
$$

With the adoption of Basel II by the BCBS in 2004 (after which followed a number of amendments in the following years), a new era began in the banks capital and risk management. Basel II regulatory framework represents a step forward in managing banks capital and risk management. Many of the shortcomings of Basel I were resolved: standardized approach (SA) for credit risk measurement have been significantly improved, new, advanced models for the credit risk measurement - internal approach have been offered, operational risks have become relevant for the capital requirement, market risk measurement has been improved, pillar 2 which brings a special qualitative improvement in Basel II, compared to Basel, have been introduced and similarly applies to the third pillar.

$$
\frac{\text { Total Capital }}{\text { Credit, market and operational risk }}=\text { Capital adequacyratio } \geq 8 \%
$$

However, beside the positive effects on the micro and macro level, such as general improvement in risk and capital management and financial stability, 
Milojević, Dimitrijević: Impact of the Serbian Banking Regulatory Framework...

some drawbacks have been manifested in recent years. The abovementioned shortcomings are identified on both micro and macro level. They may also, under certain circumstances, negatively impact the financial stability and economic growth. These phenomena are particularly observed during the global economic crisis.

Figure 1 - Basel standards development

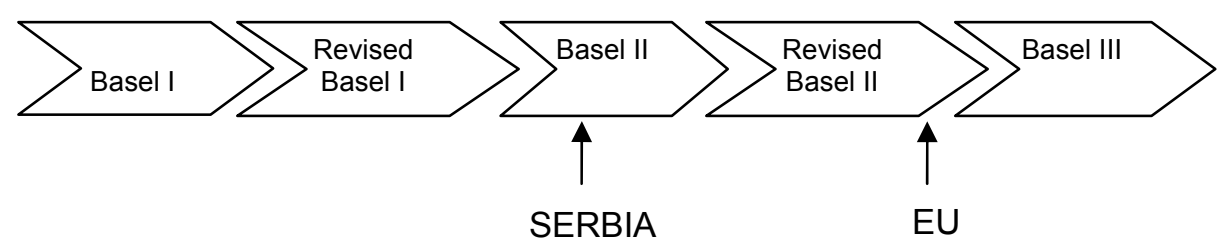

BCBS has invested considerable effort in the area of Basel II enhancements. After the global economic crisis has begun, provisions changes (and plans for further revision) have been particularly intensified. The latest revision of the provisions of Basel II introduced in 2009 and 2010 has been called the Basel III standard. With the introduction of new provisions, BCBS wants to improve global financial stability and to reduce the likelihood of crises such as the latest global economic crisis. Modifications are very ambitious and challenging for supervisors and commercial banks. Due to the aforementioned, polemics over the application of the new regulatory framework is still standing. One of the important issues is providing of a significant amount of additional capital for a large number of banks. This is one of the reasons why gradual implementation of certain segments of the new regulatory framework - Basel III is expected to begin during the period of $2013-2019$.

Basel III puts emphasis on banks capital strengthening (especially on enhancing the quality of capital), as well as the treatment of the taken risks. What is also new is that the liquidity risk and liquidity management is attracting considerably more attention. During the period 2013-2019, according to the actual plan, among others, the following will be introduced: leverage ratio, capital buffer, higher CAR minimum allowable level and new liquidity ratios. Work on countercyclical measures, macro prudential measures and other measures for strengthening financial stability is very intensive as well as is cooperation with other relevant institutions regarding the opportunities for innovation provisioning segment. It can be concluded that the revision of the Basel II in recent years has given some results. With this practice, the BCBS has continued with the introduction of the regulations in 2009 and 2010. However, there is a scope for further improvement. It is necessary to continue with further changes and provisions improvement. 
Milojević, Dimitrijević: Impact of the Serbian Banking Regulatory Framework...

\section{Coherence Between Regulatory Framework, Basel Standards and Economic Growth - World Experience}

The influence of the banking regulatory framework characteristics on economic growth is the theme that has become especially topical in the world after the Basel I have been introduced in the eighties of the last century. This topic has become even more topical by the Basel II adoption. After that, global economic crisis had its influence so that the culmination of the interest is reached for this topic.

Figure 2 - Impact transmission of the BCBS standards on the economy

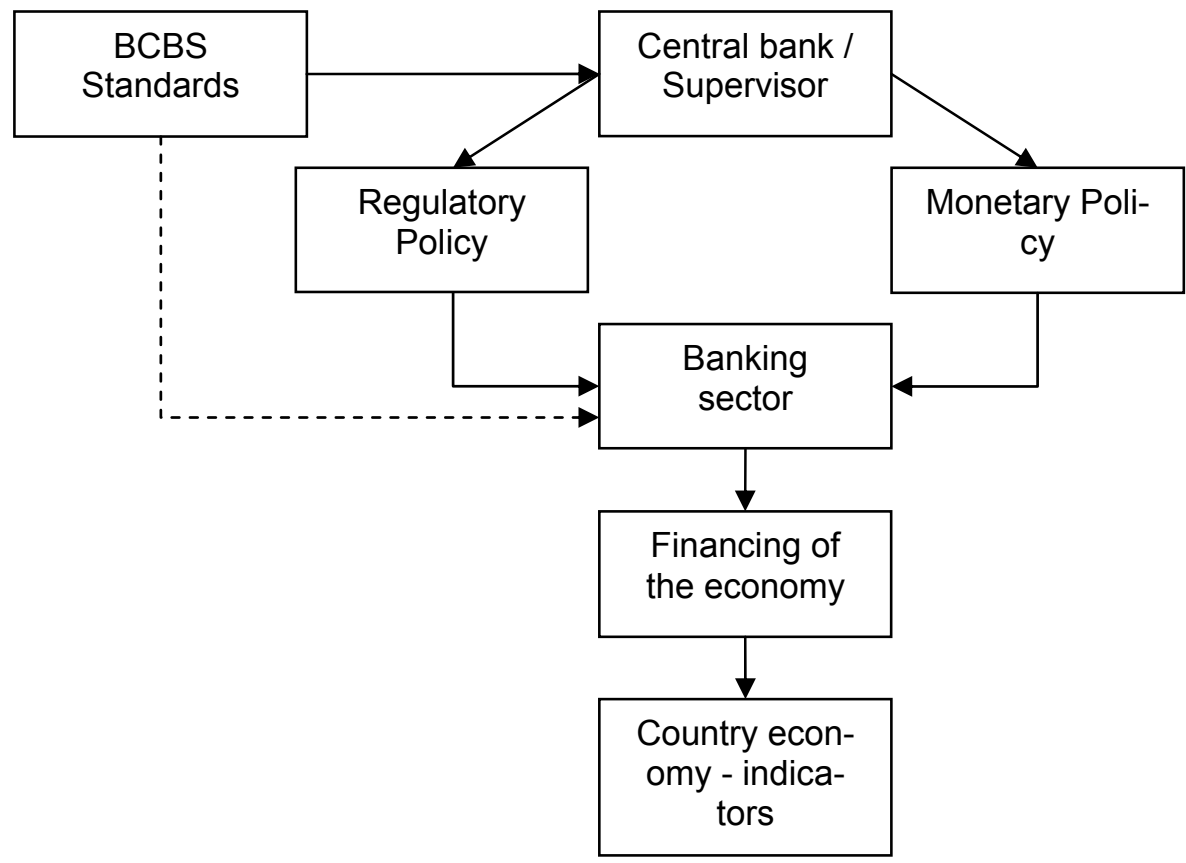

In general, the enhanced regulatory framework, i.e. better risk and capital management, should contribute to: strengthening of financial stability, preventing a financial crisis in the long term, the establishment of better conditions for economic growth. However, in practice, during the application of the Basel standards, in addition to positive opinions about the impact of these standards on the macro level, some criticism of the possible negative impact on the macro indicators, including economic growth were noted. 
We will further on present some of the views of the impact of Basel I, II and III regulatory frameworks, on the economic growth in the world. These views will be valuable for us to formulate opinion about the regulatory framework impact on economic growth in Serbia and to predicting future effects of the aforementioned influences.

It is necessary to note that the relationship between the micro and macro effects of the Basel standards is strong and dynamic. Based on the positive impact of Basel I at the micro level (strengthening of capital adequacy, competition, transparency, positive selection, etc.) we can say that the overall impact on the financial stability is positive. According to these provisions better conditions are provided for gross domestic product (GDP) and industrial production growth (Basle Committee on Banking Supervision, 1999). However, some studies have pointed that under certain conditions application of Basel can lead to the fall off the loans amount and consequently to the production and GDP. When it comes to procyclicality based on Basel I implementation, the authors generally agree that, overall Basel I capital requirement produces less procyclicality in comparison to the Basel II (Catarineu-Rabell, Jackson, Tsomocos, 2003; Gottschalk 2007).

Capital requirement for credit risk may indirectly lead to procyclicality effect in the following way: in the years of recession, due to reduced profits and / or increased banks losses, there is a need for banks recapitalization. Since in that case it is difficult to get additional capital, banks are often forced to reduce lending in order to maintain minimal acceptable level of the capital adequacy. Subsequently, the economy needing funds is having difficulties and the same can make crisis even much harder and longer. This effect will be even more striking if a country does not have a developed alternative way to raise funds, i.e. developed financial market, the different types of funds, issuance of bonds, etc. It should be noted that, when it comes to crisis, such as the latest global financial crisis, when all forms of financing are very difficult, possibilities for using some of the mentioned alternatives are also reduced. Based on the foregoing, we conclude that this effect can have much harder consequences for developing countries in relation to the economies with highly developed financial markets and diversified funding.

Some research (Chiuri, Ferri, and Majnonil 2000, p. 1-3, 6; and Basle Committee on Banking Supervision, 1999 p. 27-35), in which conclusions are summarized by various analysis and authors) pointed to certain negative effects of the Basel I implementation in the world (such as reduced capacity for lending to the economy in the East Asia during crisis in 90's of the last century). However, we can say that the overall effect, positive for financial stability and discipline, has a long term positive effect on economic growth. Basel I has also made a major step forward in the field of banks control, capital and risk management and pave the way for further improvement of the provisions 
relating to banks capital and risk management. Due to its drawbacks Basel I have a limitation in the scope and lifetime. On the other hand, Basel I have contributed to increase of the confidence in the banks and banking around the world. This also had a further positive impact on investment conditions, the positive economic climate, economic growth and other positive economic characteristics.

Regarding Basel II impact on economic growth, during the creation and implementation of the same, the following hypothesis about the expected positive effects was represented. Basel II sophisticated risk management methods should, in general, lead to lower capital requirements. According to this, a certain amount of capital could be used for other purposes / investments and economic growth initiation. Also, sophisticated risk management methods, in the same way could bring up, in general, lower real interest rates and the cheapening of the bank loans. According to this, we should again expect the positive impact on economic growth.

Previous arguments regarding the Basel II application are general. They also represent one of the main reasons for its existence. On the other hand, some studies suggest that certain negative consequences may occur in developing countries. One of the elements that require special caution is the interest margin increase in countries with low credit rating level. This can lead to a rise in loan prices, lower profits and a negative impact on economic growth. For example, interesting for us (considering Serbia's credit rating: BB- (Fitch and Standard\&Poor's) and BB (Standard\&Poor's - rating valid for Serbia in first part of 2012)) is Griffith-Jones and Persaud conclusion, according to which for the BB- credit rating, interest margin increase is 43 basis points $(0.43 \%)$ and for the BB rating 12 basis points (Griffith-Jones, Persaud p. 6, 8-10, 19, 23).

If we return to general thesis of lower interest margins and interest rates, we can note the following possible scenarios. If the banks realized the possibility with improved risk management, with less capital ${ }^{*}$ cover taken risks, then the following basic scenarios are possible (with the possible numerous subvariants):

- Interest rates decrease, which would mean keeping roughly the same interest margins and banks profitability,

- Keeping the same (or similar) level of interest rates, higher interest margins and an increase in banks profits and

- A combination of the previous two scenarios.

It is clear that the first scenario suits primarily the industry, while the second one suits the banks. The first scenario is also more favourable to economic growth than the other one. The third scenario is a compromise solution. Due to a competition factor and to other factors, this is also most probable scenario. 
Previous claims about the Basel II positive impact on economic growth are still general and conditional. Numerous studies about procyclicality (Heid, 2003; Kashyap, and Stein, J. 2004; Masschelein 2007; Financial Services Authority, 2004), which can be Basel II application consequence, particularly the application of IRB approach for credit risk measurement. Basel II (particularly IRB) is characterized by much higher capital requirements depending on the economic cycles. In general, credit ratings (especially those who are the product of IRB approach) relevant to Basel II, are characterized by a cyclic movement, i.e. they follow economic cycles. Due to economic conditions improvement, credit ratings generally improve and vice versa. Subsequently, the Basel II capital requirement has a high tendency to cyclical trends. Basel II capital requirement is on the increase in the period of economic recession, while, during the period of economic growth, is on the decreasing. These findings were specially manifested when the first global economic crisis effects had been reported. In fact, there were cases that some of the world's leading banks had officially published high levels of CAR before the crisis; after the crisis outbreak it became clear that these banks did not have enough capital to cover the taken risks, which were materialized in the form of big losses.

Due to the shortcomings of Basel II standards, which were particularly evident when the global economic crisis broke out, the BCBS and other BIS (Bank for International Settlements - Bank for International Settlements) segments accelerated work on the Basel III regulations. Basel III implementation is planed gradually during the period 2013-2019. The provisions are very ambitious and demanding, both for regulators and for commercial banks. The aim is improvement of risk and capital management, financial stability and greater resilience of the financial system on crisis challenges. Taking into consideration the requirements of the new regulatory framework, in terms of additional capital, there is a concern that this provision could have a negative influence on economic growth to a certain extent. For this reason, the BCBS have decided that implementation of the provisions of Basel III should be gradual, as well as numerous analyzes, simulations (in collaboration with a numerous relevant institutions and experts), whose findings will be useful for further calibration of the Basel III provisions.

One of the conclusions of these researches indicates that a relatively modest macroeconomic effect of Basel III can be expected, in terms of a relatively small impact on the slowdown of GDP growth during the years of implementation. Due to the application of stricter capital requirements of Basel III, GDP decline is projected at $0.22 \%$ over a period of 35 quarters since the beginning of the implementation, or $0.03 \%$ per year (Bank for International Settlements Macroeconomic Assessment Group 2010, p. 9). In addition to this modest negative effect, BIS papers (Basel Committee on Banking Supervision 2010, p. 1-6, 28-31) suggest that, in the long run, significant benefits in the prevention of the crisis could be expected. Additionally, a more stable financial envi- 
Milojević, Dimitrijević: Impact of the Serbian Banking Regulatory Framework...

ronment should have a positive impact on enabling conditions for long-term economic prosperity (after the modest effects on the GDP growth slowdown in the first years of Basel III implementation, mentioned above).

\section{Development of the Banking Regulatory Framework in Serbia and its Impact on Economic Growth}

Talking about the development of the regulatory framework of the banking business in Serbia, we may say that, following publication of Basel I regulations by the BCBS up to now, the supervisor has been trying to apply the standards of the Basel Committee in accordance with the specificities of the banking and economic systems in Serbia. The provisions of the Basel I standard have been implemented successfully in the banking sector in Serbia - BSS and we can say that they have had the positive impact on the financial stability of the country, and a high level of CAR BSS has been noted among other things in recent years (after the reforms of BSS). Positive impact on financial stability in Serbia has given the contribution to the creation of conditions for sustainable economic growth.

NBS has successfully implemented the amendments of revised Basel I standard that are related to additions of market risks. Other market risks (price risk, etc.) have become part of the capital requirements, by the provisions of the NBS in 2007, which has been a bit later than the European standards. On the other hand, taken into account that ,due to the sanctions, wars and crises in the 90's of the last century, the banking system reform, being hit hard by the crisis, has commenced later than in other developing European countries, this lagging behind is understandable.

Table 1- Capital adequacy ratio - CAR of the Serbian banking sector, during period $2000-2011$

\begin{tabular}{|l|r|r|r|r|r|r|}
\hline Year & \multicolumn{1}{|c|}{2000} & \multicolumn{1}{c|}{2001} & \multicolumn{1}{c|}{2002} & \multicolumn{1}{c|}{2003} & \multicolumn{1}{l|}{2004} & \multicolumn{1}{l|}{2005} \\
\hline CAR \% & 0.70 & 21.90 & 30.60 & 31.30 & 27.90 & 26.00 \\
\hline Regulatory minimum \% & 8 & 8 & 8 & 8 & 8 & 8 \\
\hline Year & \multicolumn{1}{|c|}{2006} & 2007 & 2008 & 2009 & 2010 & 2011 \\
\hline CAR \% & 24.70 & 27.90 & 21.90 & 21.44 & 19.91 & 19.11 \\
\hline Regulatory minimum \% & 12 & 12 & 12 & 12 & 12 & 12 \\
\hline
\end{tabular}

Based on data from National Bank of Serbia retrieved from http://www.nbs.rs

After strengthening the aforementioned regulations, and subsequent strengthening of risk management segment, through Decision on risk man- 
agement has been repeatedly revised over the years, in order to bring this area as much as possible closer to the Basel standards i.e. European standards of risk management in the banking industry. In this way, a step towards the implementation of Basel II in Serbia has been made, and full implementation (after extensive preparations of NBS and commercial banks) thereof started on December $31^{\text {st }}, 2011$.

Although the implementation of Basel II has started in Serbia, the future holds challenges to the regulatory framework. Among other things, these challenges are related to acquiring a more sophisticated approach to risk measurement and capital, such as the IRB (Internal Rating Based) approach for credit risk, internal models for market risk, the AMA (Advanced Measurement Approaches) for operational risk, ICAAP (Internal Capital Adequacy Assessment Process), and to make progress in the development of the rating, improving stress testing methodology, monitoring macroeconomic risks, further reform of the Decision on the classification of the balance sheet assets and off-balance sheet items and treatment of the provision for the estimated losses, etc. The challenge is the issue of what will be the change in regulatory capital and the CAR in the future. The period as of 2014 will be particularly interesting but also the period 2012 - 2013 because the NBS (through its Decision on the capital adequacy of banks, which came into force on December 31,2011), decided to introduce a transitional period until 2014 in the form of gradual implementation of deductibles of capital, or core capital (if there are no additional changes in the regulation of this area).

In the end of 2011 CAR BSS amounted to $19.11 \%$, taking into account Basel II standards (and the transitional provisions relating to the above mentioned deduction from capital), which is 0.54 percentage points lower, or $2.75 \%$, compared to the value in September 30, 2011 when CAR BSS was the last time calculated by the methodology based on the revised Basel I standards. This decrease in CAR can be primarily attributed to the implementation of new regulations. The amount of decrease is not that high at this moment to significantly affect the BSS, but it should be noted that the gradual (more demanding in terms of capital) application of the provisions regarding capital deduction items until 2014 have an impact on the decline in CAR BSS (which, to a certain extent, happened in Q1 2012.).

Along with these challenges, primarily related to Basel II, the NBS and commercial banks will bring more attention to the challenges of the implementation of Basel III standards. In recent years, certain basics are in place in the banking sector and regulations, which may allow easier use of certain segments of Basel III regulations. Thus, for example, due to some specificities of BSS and associated regulations, that one has relatively readily faced the global economic crisis compared to many other developed banking sectors of the world economy. BSS has managed to remain profitable in recent years 
Milojević, Dimitrijević: Impact of the Serbian Banking Regulatory Framework...

(though some banks have recorded significant losses), but to maintain this trend in the future, a number of challenges need to be faced, such as the higher credit risk in the country. The important thing related to this issue is the economic expectations of the BSS. In fact, perhaps more than ever, we need to give strong support to the strengthening of the economy and the sustainable economic growth of the country. For the country's economy, which is (again) fragile due to the negative effects of the global economic crisis, strong financial support of BSS is surely necessary.

Figure 3 - The growth rate of capital and the share of capital in total liabilities of the Serbian banking sector in the period 2003 - 2011

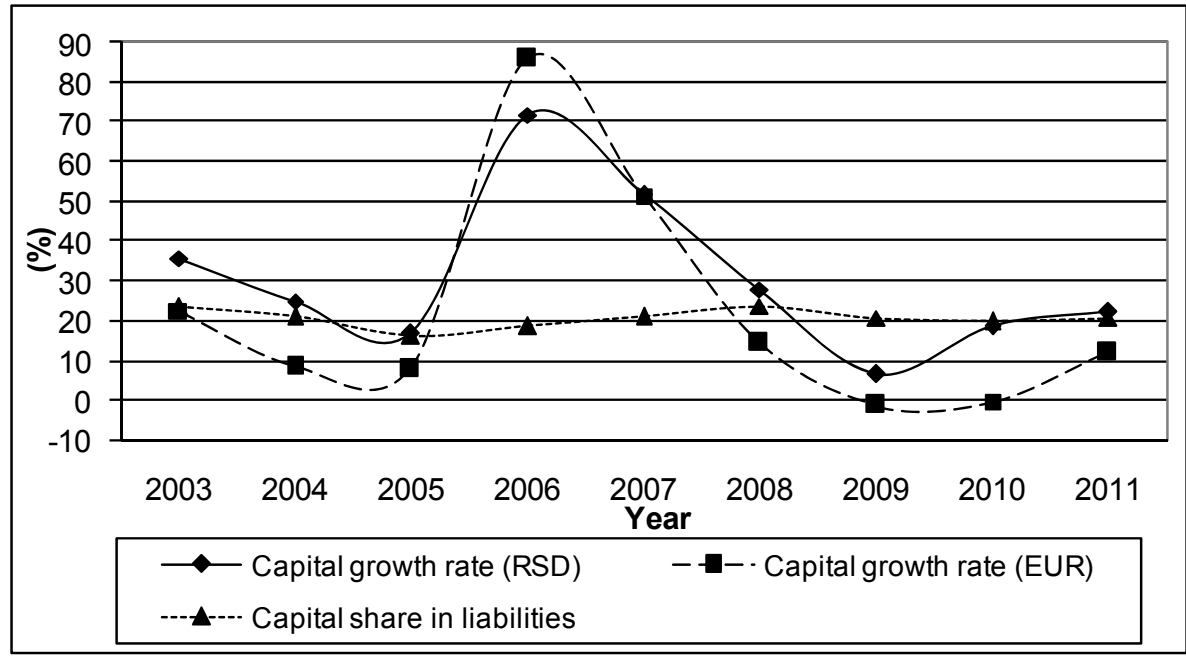

Based on data from National Bank of Serbia retrieved from http://www.nbs.rs

It should be noted that, in Serbia, the minimum allowable CAR has long been at $12 \%$, thus probably being, among other things, just one of the factors for an easier transition from Basel II to Basel III standard (compared to the countries with lower minimum allowed CAR in comparison to Serbia). Let us recall that during the last period the NBS applied some countercyclical measures over the periods of economic expansion and periods of economic recession. In 2006, due to strong growth in loans to retail, which affected the growth of inflation, the NBS decided to introduce this ratio (Decision on the harmonization of gross household lending with banks' equity of banks, Official Gazette of the Republic of Serbia, Nos. 39/2006, 49/2006, 64/2006, 31/2007, 77/2007, $35 / 2008,65 / 2008$ and 12/2009). Indirectly, the NBS monetary policy caused a significant CAR increase of the BSS. Therefore, this ratio has, among other things, had significant positive impact on the ratio equity / total liabilities, i.e. 
the fact that banks in Serbia have been relatively highly capitalized, during the last years. In this way, the application of leverage ratios, which advocates for Basel III in Serbia, should be much easier than in some other countries whose banking sectors are much smaller (in percentage) capitalized in relation to the Serbian. The fact that the share of total capital in liabilities of BSS has over reent years been about (or above) $20 \%$, speaks in favor of this fact.

Figure 4 - Return on assets (ROA) and equity (ROE) of the Serbian banking sector in the period 2003 - 2011

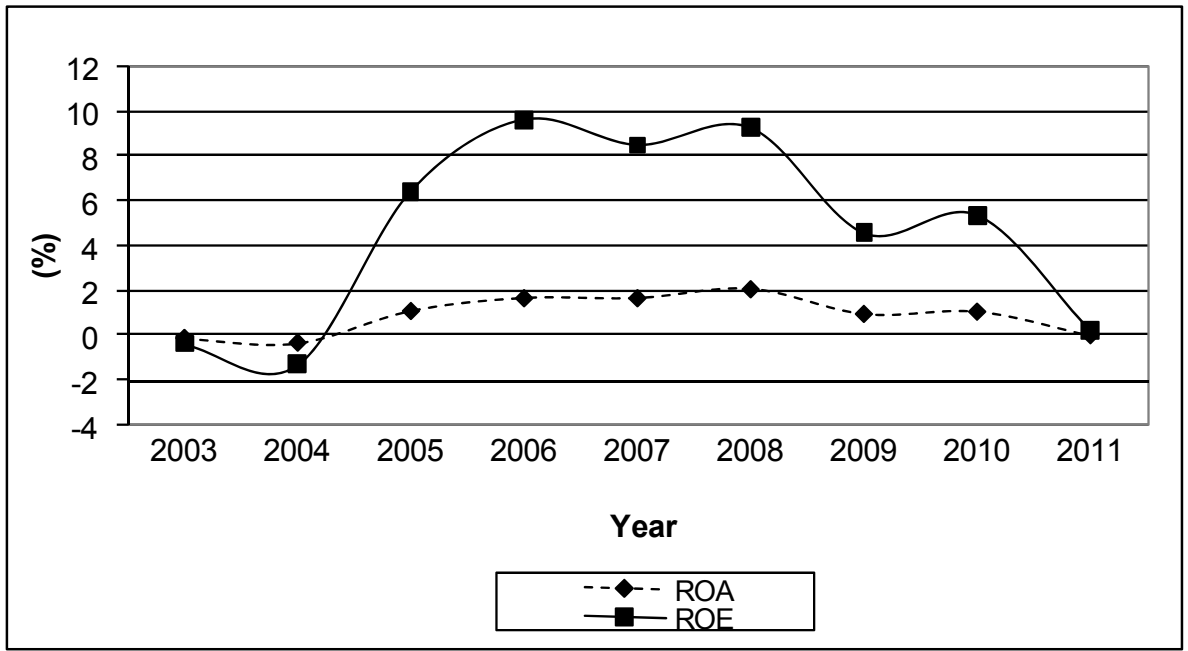

Based on data from National Bank of Serbia retrieved from http://www.nbs.rs

The next important issue is the effect that makes the necessity for further strengthening of the banks' capital base due to regulations, higher costs of financing, pricing of financial products and achieving lower return on equity. We can say that to some (relatively small) extent, these effects have been felt during the past years. However, further strengthening of the capital base of banks profited in the long-term when it comes to stability of the banks and of the entire financial system (also the above mentioned had a positive influence by creating the conditions for sustainable economic growth). The banks and the financial system as a whole have much more readily faced the global financial crisis (although there are some banks in Serbia which have experienced significant problems and failed to comply with the aforementioned general tendency).

To mention again that due to the fact that BSS, through specific local regulations, further strengthened the capital base (and that BSS has a high share of capital in liabilities), can be perceived as an advantage to the future applica- 
Milojević, Dimitrijević: Impact of the Serbian Banking Regulatory Framework...

tion of Basel III (hopefully after the successful implementation of Basel II). In the EU today, there are very relevant complaints claiming that banks will have big problems with the provision of additional capital when Basel III comes into force (the regulatory framework which is generally, in terms of capital requirement, significantly more demanding than Basel II). On the other hand, the BSS sector has a potential to cope with the future implementation of Basel III more easily when it comes to a potential problem with a lack of capital announced by many EU banks.

Figure 5 - The GDP growth rate of Serbia during the period 2001 - 2011

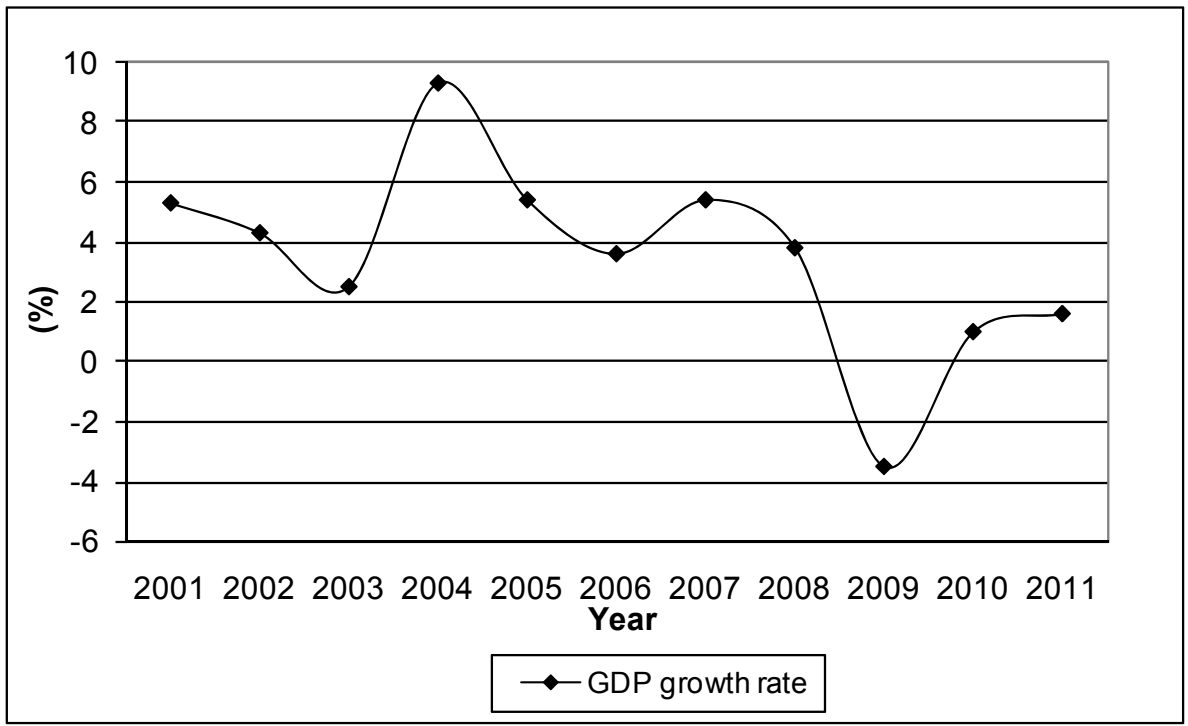

Based on data from Statistical Office of Republic of Serbia retrieved from http://webrzs.stat.gov.rs/axd/index.php

We can say that the previous application of the Basel standards in Serbia, as part of the regulatory policy and in addition to a positive contribution to the stability of the banking and financial system, brought a long-term contribution to the creation of conditions for sustainable economic growth. Regarding conditions for sustainable economic growth in Serbia, various interesting research, books, etc. have been published, during the last few years (Savić, Bošković, 2012; Dimitrijević, Ivović, 2008; Filipović 2012; Savić, Bošković 2012).

The GDP growth rate in Serbia have had had significant fluctuations over the past ten years, but these cannot be attributed to the application of Basel standards, but rather to other factors not related to regulatory policy concern- 
ing BSS. In addition, there are research results presented in the author's monograph (Masschelein, 2007), especially the part related to the analysis of the impact of up to date implementation of the Basel provisions and capital requirements on procyclicality in Serbia.

Therefore, based on conducted analysis, it was concluded that the implementation of the Basel standards and capital requirements had no effect on the development of procyclicality in Serbia, but on the contrary, it was a stabilizing factor in terms of financial stability and it was creating the conditions for sustained economic growth. Since, at the beginning of the implementation of Basel II standards, banks in Serbia have used relatively simple approaches (primarily referring to standardized approach for credit risk measurement SA), we expect that in the short term there will be no significant development of procyclicality due to the implementation of Basel II. Higher implementation of IRB approach in the future would require considerably higher caution as regards procyclicality, but taking into consideration that Basel III puts an emphasis on reducing procyclicality, timely implementation of Basel III should have a limiting influence on the development of procyclicality.

\section{Prediction of the Possible Impact of Further Basel Standards Implementation in Serbia on Economic Growth}

When we talk about predicting the possible impact of further implementation of the Basel standards in Serbia on the country's economic growth, it is necessary to state that we expect that regulatory framework in Serbia in near future highligh in parcticular:

- Further mastering of the application of Basel II standards, with special emphasis on the mastery of sophisticated approaches to risk and capital management (IRB, AMA);

- Further reform of the Decision on the classification of the balance sheet assets and off-balance sheet items and treatment of the provision for the estimated losses;

- Application of the transitional provisions by 2014, the treatment of capital deduction items when computing the CAR;

- Gradual preparation for the Basel III implementation (whose implementation will begin in EU in the period 2013-2019, while for Serbia it is expected that Basel III implementation plan will be made in the future).

To determine the impact of further Basel standards implementation in Serbia on the economic growth, observing the period of the next few years, it is necessary to identify trends in terms of changes in the value of CAR BSS, or whether and to what extent shall we expect a drop or increase in the value of 
CAR BSS in the future. Based on the above, depending on whether one expects that banks will need additional capital increase or conditions for the capital reallocation and the capital placement in other economy areas, we will try to find out the possible impact of these changes on the economic growth of the country.

Having on mind the above, we will try to give a forecast of changes in CAR based on the application of Basel II and the related regulations of NBS. We have seen that the value of CAR BSS on December 31, 2011 (with the application of Basel II) was down by $2.75 \%$ compared to the value on September 30, 2011 when CAR BSS was calculated for the last time by methodology based on the revised Basel I standard. However, this change would be significantly higher if the NBS has not decided on a gradual implementation of deductibles of capital, which will have the full effect in 2014. On the other hand, banks in Serbia, for the calculation of capital requirements for CAR, still do not use internal approaches (IRB, AMA, etc.). When this happens, we might expect certain trends of decreased capital requirements and increased CAR.

These factors could (along with any additional changes of the classification of balance sheet and off balance sheet) mark the change in the value of CAR in 2012, 2013 and 2014, while the effects of the implementation of Basel III will probably start being visible in subsequent years in Serbia (it is still not certain when Basel III will commence in Serbia). With the above mentioned, for prediction of effects of the Basel standards implementation on economic growth in the next few years as one of the inputs, we will use the results of the quantitative analysis of changes in capital requirements, i.e. CAR, presented in the paper, "Perspectives of Banks Capital Requirement Changes Due to the Basel Standards Implementation" from 2011 (Milojevic, 2011).

As a basis for this analysis, among few other things, BCBS quantitative studies - QIS 5 have been used (Basel Committee on Banking Supervision, 2006). QIS 5 has come to certain conclusions concerning the change in the level of required capital in the banks due to the implementation of Basel II. QIS 5 provides us with a comparative analysis of the application of Basel II in different countries, i.e. in developed and developing countries. Besides, we have an insight into the comparative analysis of the implementation of Basel II in banks with different characteristics and profiles. Also, there has been the comparison of the effects of application of Basel II by the use of different approaches of Basel II.

In QIS 5, for the quantitative analysis of the work (Milojevic, 2011), there were especially significant results for the banks from the category: "Other countries outside the G10 Group 2" and "CEBS Group 2." These results have been adjusted as much as possible to specificities of BSS and CAR calculations in Serbia (based on available data, primarily on the NBS web site). 
Milojević, Dimitrijević: Impact of the Serbian Banking Regulatory Framework...

For the easer monitoring of further analysis we state further clarifications:

1. CEBS (Committee of European Banking Supervisors) countries (in addition to the CEBS members G10) that participated in the QIS 5 were: Bulgaria, Cyprus, Czech Republic, Finland, Greece, Hungary, Ireland, Malta, Norway, Poland and Portugal.

2. "Countries outside the G10" in QIS 5 study were: Australia, Bahrain, Brazil, Chile, India, Indonesia, Peru and Singapore.

3. Division of Banks into Group 1 and Group 2: Group 1 consists of banks that meet the following criteria: core capital (Tier 1) higher than 3 billion EUR, the Bank's business has diversified and the Bank is internationally oriented. Banks that do not meet all three conditions mentioned above belong to the second group.

Results from the "Prospects for change in bank capital requirements from the application of the Basel standards", were as follows:

1. Changing of the BSS capital requirements based on category "Countries outside the G10, Group 2" from QIS 5: 24.0\% (if using a Standardized approach for credit risk measurement - in the further analysis SA1), 6.6\% (if using IRB approach to measure credit risk - in the further analysis IRB1) and 15.3\% (when used combination of SA and IRB approach - in the further analysis COM1).

2. Changing of the BSS capital requirements based on category "CEBS Group 2" from QIS 5: -3.3\% (if using a standardized approach - in the further analysis SA2) $-17.6 \%$ (if using IRB approach - in the further analysis IRB2) and $-10.5 \%$ (when used combination of SA and IRB approach - in the further analysis COM2).

3. Changing of the BSS capital requirements based on combined effects of the first two categories: $10.4 \%$ (if using a standardized approach - in the further analysis SA3) $-5.5 \%$ (if using the IRB approach - in the further analysis IRB3) and $2.4 \%$ (when used combination of SA and IRB approach - in the further analysis COM3).

Based on these results, we have calculated what would be the change in BSS capital requirements (in billions of RSD) if we started from the values relating to BSS capital adequacy, as of September 30, 2011 (the last CAR BSS calculation according to Basel I revised standard). Using the same data we have calculated the change in the level of CAR BSS (depending on the scenario of -2.88 percentage points to 2.11 percentage points). Changes of CAR BSS are presented in the table in the order from negative to positive.

It has to be noted that, in practice, the results of previous analyzes of changing capital requirements, these changes, when it comes to BSS, should be interpreted as a direct effect on the CAR (i.e. that also covers changes in the levels of regulatory capital). Thus, it is characteristic for the BSS that the implementation of new regulations on December 31, 2011 led to a total decline 
Milojević, Dimitrijević: Impact of the Serbian Banking Regulatory Framework...

in capital requirements, but also to a decrease in regulatory capital and to a total decline in CAR of up to $2.75 \%$. In order to make the next simulations of CAR BSS changes simple and comparable with the changes in the QIS 5 and others similar analyzes, the concept of change in capital requirements and changes in CAR has been identified in presented simulations, i.e. the effect of changes in capital requirements in simulation includes the effect of changes to the regulatory capital and the total impact of the change in CAR. In this way, we obtain the CAR BSS represented change.

Table 2 - Simulation of the changes of CAR and capital requirement level for the risk coverage of the Serbian banking sector

\begin{tabular}{|l|l|l|l|l|l|l|l|l|l|}
\hline & SA1 & COM1 & SA3 & IRB1 & COM3 & SA2 & IRB3 & COM2 & IRB2 \\
\hline $\begin{array}{l}\text { The change } \\
\text { of the BSS } \\
\text { capital } \\
\text { requirement } \\
\text { (\%) }\end{array}$ & 24,00 & 15,30 & 10,35 & 6,60 & 2,43 & $-3,30$ & $-5,50$ & $-10,45$ & $-17,60$ \\
\hline $\begin{array}{l}\text { The change } \\
\text { of the BSS } \\
\text { capital } \\
\text { requirement } \\
\text { (bn RSD) }\end{array}$ & 58,88 & 37,54 & 25,39 & 16,19 & 5,95 & $-8,10$ & $-13,49$ & $-25,64$ & $-43,18$ \\
\hline $\begin{array}{l}\text { The change } \\
\text { of BSS } \\
\text { CAR (per- } \\
\text { centage } \\
\text { points) }\end{array}$ & $-2,88$ & $-1,84$ & $-1,24$ & $-0,79$ & $-0,29$ & 0,40 & 0,66 & 1,25 & 2,11 \\
\hline $\begin{array}{l}\text { * Values at the reporting date 30.09.2011 - the last BSS CAR calculation under Basel I re- } \\
\text { vised standard }\end{array}$ & & & & & & & & & \\
\hline
\end{tabular}

Based on the analysis of Milojevic N. (2011b) as well as data from National Bank of Serbia

Based on the simulated change in CAR values due to implementation of Basel CAR standards in the future, we will simulate the potential impact of changes in CAR to GDP in the future.

In this study, we have already mentioned that more sophisticated regulatory standards for capital and risk management should, in general, make a positive impact on the economic growth of the country, but conditionally. This thesis is based on the individual elements which we have already elaborated. Advanced risk management methods of Basel II, should, in general, lead to lower capital requirements. In this way, the certain level of capital could be placed for other purposes and be the engine of economic growth. In addition, advanced methods of risk management could, in the same way, lead to lower interest rates and the cheapening of bank loans and therefore we are talking about the positive impact on economic growth again. 
For the further simulation, one of the relevant elements are the results in the BIS document (Bank for International Settlements Macroeconomic Assessment Group, 2010) in which the possible impact of changes in GDP, due to the implementation of Basel III, has been analyzed. We have decided for the mentioned analysis, as it is one of the relatively recent ones, but it is also a result of the relatively long study (which took into account the significant number of other relevant studies). Also, the above study included a large number of eminent international experts, a number of the world's major institutions (central banks, IMF, etc.) Mentioned research has addressed the impact of changes in the level of capital adequacy due to the implementation of Basel III on GDP, but we have found out that the result of the research can be useful information as one of the relevant elements of the study (after conducting the analysis of possible values CAR BSS, taking into account the core capital and relevant principles of Basel III, as well as the results of the aforementioned studies BIS).

Certainly, there are many other studies on this topic in the relevant world literature We also had them in mind as one of the possible potential inputs for our research, but we have opted for BIS result because we believe that, in comparison to the available literature for the simulation it is the most relevant (and considering that in Serbia, we have a modest base and a modest number of time series data required for the implementation of the above simulations, we believe that the aforementioned results BIS represent a good source of information for our research).

According to one of the results of this BIS research, we can expect a decline in GDP of $0.19 \%$ (Bank for International Settlements Macroeconomic Assessment Group, 2010, p. 1.8) due to the CAR (targeted) growth by 1 percentage point (due to the application of the methodology of Basel III). Applying the aforementioned percentage (as a benchmark for a positive or negative impact on GDP) on change of CAR BSS level, in Table 3, we come to Scenario 1. - changes of GDP due to changes in CAR BSS. The result of Scenario 1 is that, depending on the application of different methods for measuring credit risk, GDP records a change in the range from $-0.49 \%$ to $0.36 \%$.

Scenario 2 is a Scenario 1, adjusted in the following sense: given that the BSS has a relatively high value of the CAR (which was presented on 31.12.2011), i.e. significant capital reserves to cover risks that are higher than the values of taken risks, we conclude that the BSS can more easily cope with negative effects (if they occur) of the further implementation of the Basel standards, in terms of the decrease in CAR, as compared to other banking sectors which have lower capital reserves, above the minimum requirement. In this way, the potential negative impacts on GDP can be absorbed by the banks that currently have a higher value of the CAR. This assumption was applied taking into account the analysis and conclusions regarding the possi- 
Milojević, Dimitrijević: Impact of the Serbian Banking Regulatory Framework...

bility of BSS to cope with procyclicality (Milojevic, 2011a, p. 210-225). Based on these findings about the possibility for BSS to cope with the negative scenario regarding the Basel standards application, we are now able to simulate how the BSS will cope with significantly lower increases in capital requirements from Tables 2 and 3.

Table 3 - Simulation of the impact of the Serbian banking sector CAR change on the GDP due to the Basel standards application

\begin{tabular}{|l|l|l|l|l|l|l|l|l|l|}
\hline & SA1 & COM1 & SA3 & IRB1 & COM3 & SA2 & IRB3 & COM2 & IRB2 \\
\hline $\begin{array}{l}\text { The change of } \\
\text { BSS CAR } \\
\text { (percentage } \\
\text { points) }\end{array}$ & $-2,88$ & $-1,84$ & $-1,24$ & $-0,79$ & $-0,29$ & 0,40 & 0,66 & 1,25 & 2,11 \\
\hline $\begin{array}{l}\text { The GDP } \\
\text { change based } \\
\text { on BSS CAR } \\
\text { change (\%) } \\
\text { Scenario 1 }\end{array}$ & $-0,49$ & $-0,31$ & $-0,21$ & $-0,13$ & $-0,05$ & 0,07 & 0,11 & 0,21 & 0,36 \\
\hline $\begin{array}{l}\text { The GDP } \\
\text { change based } \\
\text { on BSS CAR } \\
\text { change (\%) } \\
\text { Scenario 2 }\end{array}$ & $-0,15$ & $-0,08$ & $-0,02$ & $-0,01$ & 0,00 & 0,07 & 0,11 & 0,21 & 0,36 \\
\hline $\begin{array}{l}\text { The GDP } \\
\text { change based } \\
\text { on BSS CAR } \\
\text { change (\%) - } \\
\text { Scenario 3 }\end{array}$ & 0,21 & 0,28 & 0,34 & 0,35 & 0,36 & 0,43 & 0,47 & 0,57 & 0,72 \\
\hline
\end{tabular}

According to these results, the correction of Scenario 1 results, with a decrease in CAR, has been done .It has been foreseen that GDP decline will only be partially achieved, i.e. $2 \%, 5 \%, 10 \%, 25 \%$ and $30 \%$ out of predicted decrease, as seen from the lowest GDP decline from the Scenario 1, which is $-0.05 \%$, to the most significant drop from the Scenario 1 of $-0.49 \%$. In this way, we have come up with new, milder negative values in Scenario 2, i.e. GDP fall in the range of $-0.15 \%$ to almost neutral effect i.e. $0 \%$ change in GDP. Positive values change in GDP in Scenario 2 is the same as positive value change in GDP in Scenario 1.

In Scenario 1 and 2 we are considering the short / medium term (approximately 4 years) change in GDP due to changes of CAR BSS. When it comes to Scenario 3, changes in GDP due to changes of CAR BSS, this scenario is about adding long-term impact on already established short / medium-term impact calculated in Scenario. Namely, in this study, we have already concluded that the application of Basel II, more sophisticated regulatory framework that delivers better risk management, should create safer and more sta- 
ble financial system and, therefore, in the long run provide a positive climate for economic growth of the country (and for macroeconomic stability).

Based on the above, we can talk about an additional positive impact on GDP. For the purposes of this analysis, the third scenario was added and the aforementioned long-term positive effect has been set at the same level as the highest percentage of growth obtained in one of the Scenarios 2, which is IRB2 amounting to $0.36 \%$ (primarily due to the quality of risk management). In this way, in the Scenario 3, to both values from each of the Scenarios 2 the amount of $0.36 \%$ was added, to reach the expected total value of the implementation of Basel II in the long run.

Figure 6-Three scenarios with different sub-variants of the BSS CAR changes impact on GDP change due to the Basel standards application

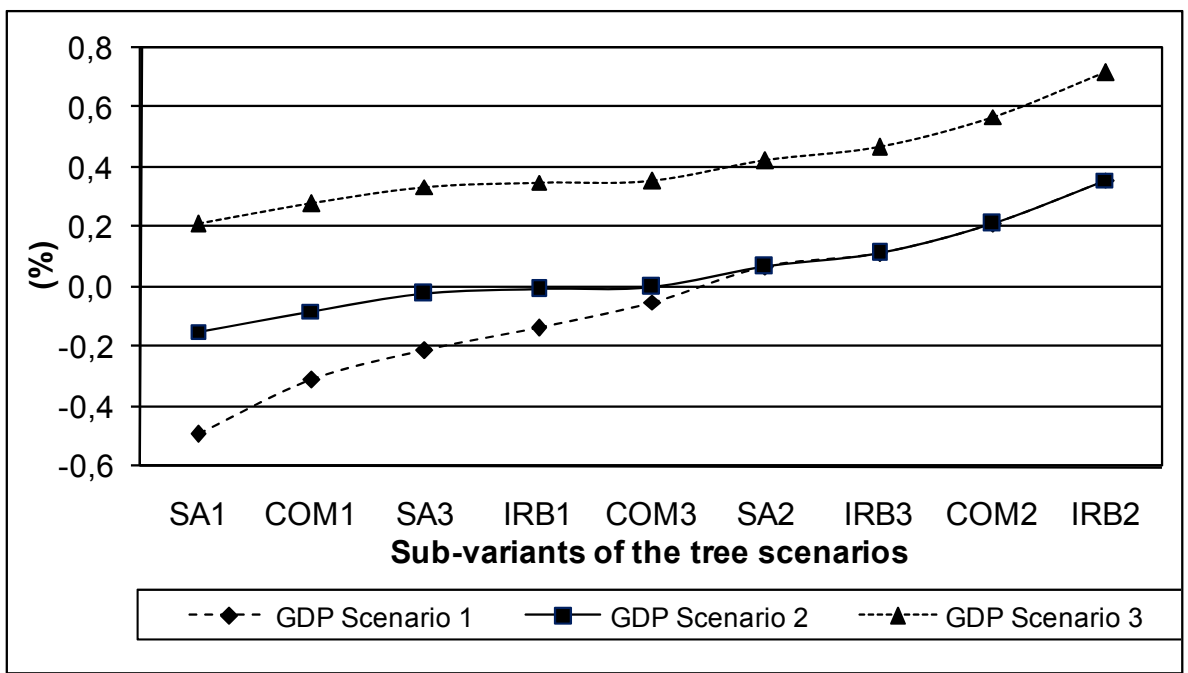

* The values of the Scenarios 1 and 2 are the same for sub-variants: SA2, IRB3, COM2 and IRB2

Finally, based on the results from Table 3 (also presented in Fig. 6, where the results of Scenario 3 are sublimated), we can conclude that in Serbia, due to the further Basel standards implementation (i.e. effects of full Basel II implementation), a slightly positive impact on GDP is most likely. If we talk about the short / medium-term effects (approximately 4 years), we can say that the most probable range of the total effect, from a neutral effect on economic growth, is up to $0.36 \%$ growth, while the long-term effect extends this range up to $0.72 \%$. In our analysis, we have seen that there is a possibility of the fall in GDP due to the implementation of Basel II (to a level of $-0.49 \%$ ), but due to the characteristics of the banking sector in Serbia and the course of the implementation of Basel II and the related regulations in Serbia, we are closer to 
believe that before achieving potentially negative effect, most of the possible CAR BSS decrease would be amortized without a significant impact on GDP.

However, the conclusions at the beginning of the study, on the possible development of procyclicality in a stress scenario suggest caution, as well as the fact that the developing countries are advised on increased caution in the implementation of the new Basel standards. However, there is still an open issue on further effect of some supporting elements of relevant banking regulations (such as the reserve treatment for potential losses) for the further implementation of the Basel standards in Serbia. We should not forget that the claims about the potential and relatively mild positive impact of Basel II on GDP are general, but the realization of these claims largely depends on the economic cycles, which among other things caused the necessity for the Basel III provisions.

Since we have made reference to the Basel III regulations in different contexts several times, we should mention that it would be favorable in the future to do the simulation and quantitative analysis of the Basel III implementation impact on the macro parameters in Serbia (similarly like it was performed for the simulations of the Basel standards impact - primarily the Basel II on Serbian GDP). However, we believe, that such quantitative analysis should be done after obtaining more information (and longer time series) on the implementation of Basel II in Serbia. Practically, a good time for the said would be upon having available relevant information about the situation in Serbia regarding the relevant micro and macro parameters, after full implementation of Basel II and the impact made on those parameters. By then, we should have other relevant data for the simulation, such as the time frame for the implementation of Basel III in Serbia and many other necessary information for high quality quantitative analysis of the impact of Basel III on the macro parameters in Serbia.

Similar positive trends (like those that enabled application of the provisions of the Basel), are expected from the implementation of Basel II (and of the future revised provisions of the Basel and Basel III). Foreign investors should feel greater security of their investments in Serbia, i.e. Serbia would be more attractive for new investment. Also, due to the use of more sophisticated methods of measuring risk, companies that are clients of banks and that need funds, will be forced more than ever to take care of their business, balance sheets, corporate values and all business performances that can enable easier and cheaper fund gaining (this should decrease grey economy).

Similarly to companies, the Government of Serbia and other relevant state authorities will be interested in Serbia's higher credit rating (there are similar tendencies in terms of rating municipalities and other government entities). To achieve this, aforementioned state bodies will be more interested and motivated to increase economic and other relevant performances for credit rat- 
ings. All this should have a positive impact on economic growth in Serbia, in the medium and long term.

When it comes to the effects of further implementation of the Basel standards on capital allocation, based on the available information / analysis / experiences of other countries, it is expected that not all economic entities, branches and business will feel the same effects that may affect their future development, and therefore have contribution to the economic development of the country. Capital-intensive sectors and industries may be the greatest winners of the implementation of Basel II, as well as the best rated largest companies (there are still no externally rated companies in Serbia, but until getting external ratings, good internal ratings will affect more available and cheaper means). On the other hand, during the previous years of the Basel II implementation of in the world, there was a certain fear that small and mediumsized enterprises will have a more difficult access to resources, but it can be said that it is more likely that this group will not be discriminated in treatment with banks, after the implementation of Basel II in Serbia.

Summing up the results, we can say that through further careful Basel standards application in Serbia, the positive effects on GDP should prevail potential negative effects. Of course, prior to this, a lot of effort is needed and investments of all relevant parties.

\section{Conclusion}

In this study we have presented a dynamic relationship between the regulatory framework of the banking business and economic growth. The topic is a very important issue for the world economy, but for Serbia (which began with the implementation of Basel II on December 31,2011) is also of paramount importance. In the remainder of this decade, Basel III standard will make (and after) a strong impact on the banking, financial stability and economic growth in the world, especially in Europe, and inevitably in Serbia. Having on mind the above, we have presented the characteristics of the aforementioned relationship in the world, but we are primarily oriented to the effects analysis relevant for Serbia.

Based on the research in this study, we have concluded that the current implementation of the Basel standards in Serbia, as part of regulatory policy, besides positive contribution to the stability of the banking and financial system, have had a long-term contribution to the creation of conditions for sustainable economic growth. The GDP growth rates in Serbia have had significant fluctuations over the past ten years, but we cannot assign these oscillations to the implementation of Basel standards, but rather to other factors not related to regulatory policy referring to the BSS. 
We have emphasized that more sophisticated regulatory standards for capital and risk management should, in general, make a positive impact on the economic growth of the country, but conditionally. Advanced risk management methods of Basel II, should, in general, lead to lower capital requirements. i.e. a certain level of capital that could be placed for other purposes as to be an engine of economic growth. In addition, advanced methods of risk management would, in the same wa,y lead to lower interest rates and to cheapening of bank loans. Therefore, in this way, we are also talking about the positive impact on economic growth.

Based on the quantitative analysis presented in this study, and based on performed simulations, we have the following projections. In Serbia, due to the further implementation of the Basel standards (i.e. effects of full implementation of Basel II) a slightly positive impact on GDP is most likely. If we talk about the short / medium-term effects (approximately 4 years), we can say that the most probable range of the total effect starting from a neutral effect on economic growth, up to $0.36 \%$ growth, while the long-term effect extends the range up to $0.72 \%$. In our analysis, we see that there is a possibility of the fall in GDP due to the implementation of Basel II (to a level of $-0.49 \%$ ), but due to the characteristics of the banking sector in Serbia and the course of the implementation of Basel II and the related regulations in Serbia, we are closer to believe that, before achieving potentially negative effect, most of the possible CAR BSS decrease would be amortized without a significant impact on GDP.

However, the conclusions at the beginning of the study on the possible development of procyclicality in a stress scenario suggest caution, as well as the fact that the developing countries are advised on increased caution in the implementation of the new Basel standards. However, there is still an open issue on further effect of some supporting elements of relevant banking regulations (such as the treatment of the provision for the estimated losses) for the further implementation of the Basel standards in Serbia. We should not forget that the claims about the potential and relatively mild positive impact of Basel II on GDP are general, and also one of the major motives for its existence, but the realization of these claims largely depends on the economic cycles, which among other things, caused the necessity for the Basel III provisions.

Quantitative and qualitative analyses, conducted during the research presented in this study, indicate a significant potential for further positive effects, among other things, on economic growth, due to the implementation of the Basel standards in Serbia. The positive results of the application are very dependent on adequate preparation, analysis and actions of all relevant parties in the implementation of the Basel standards. Summing up the results, we can say that through further careful Basel standards application in Serbia, the positive effects on GDP should prevail potential negative effects. Of course, prior to this, a lot of effort is needed and investments of all relevant parties. 
One of the scientific contributions of this study is that the research of the influence of the banking business regulatory framework in Serbia on the economic growth will help the researchers who will deal with this issue in the future. There are just a few published analyses in Serbia publicly available, that are dealing with the Basel II macroeconomic effects in Serbia, because it is a relatively new issue in our country, Thus, in the future, we can expect new work of researchers in Serbia (especially as there will be longer time series, necessary data for analysis, more extensive and better data, etc.). In relation to the above issues, the impact of future application of Basel III on the economic growth in Serbia will be in the focus. Acording to expectations, the Basel III should continue to make, in general, positive effects on financial stability and to create the conditions for sustained economic growth.

\section{References:}

-Bank for International Settlements Macroeconomic Assessment Group. (2010). Assessing the macroeconomic impact of the transition to stronger capital and liquidity requirements. Final Report.

-Basel Committee on Banking Supervision. (2005). Fifth quantitative impact study (QIS5). Basel: BIS - Basel Committee.

-Basel Committee on Banking Supervision. (2010). An assessment of the long-term economic impact of the new regulatory framework. Basel: Bank for International Settlements.

-Basle Committee on Banking Supervision. (1999). Capital Requirements and Bank Behaviour: The Impact of the Basle Accord. Working Paper no. 1.

Catarineu-Rabell, E., Jackson, P., \& Tsomocos, D.P. (2003). Procyclicality and the new Basel Accord - Banks' Choice of Loan Rating System. London: Bank of England. Working Paper no. 181.

Chiuri, M.C., Ferri, G., \& Majnonil, G. (2000). The Macroeconomic Impact of Bank Capital Requirements in Emerging Economies: Past Evidence to Assess the Future. The World Bank, Finance, Development Research Group and the Financial Sector Strategy and Policy Department. Policy Research Working Paper 2605.

Dimitrijević, B., \& Ivović, M. (2008). Tržište i prirodna ravnoteža - slučaj kvantitativne teorije novca. Poslovna ekonomija, 2(3), 133-148.

Filipović, M. (2012). Sustainable Development of Serbia at the beginning of the 21st Century. Industrija, 40(1), 133-148.

-Financial Services Authority. (2004). Procyclicality of capital requirements under Basel II: Aide memoire.

Gottschalk, R. (2007). Basel II implementation in developing countries and effects on SME development. Brighton: Institute of Development Studies University of Sussex.

Griffith-Jones, S., \& Persaud, A. . The Pro-Cyclical Impact of Basle II on Emerging Markets and its Political Economy. Retrieved from http://www.financialpolicy.org/financedev/persaud.pdf

Heid, F. (2003). Is regulatory capital pro-cyclical?, A macroeconomic assessment of Basel II. Deutsche Bundesbank. (preliminary version). 
Milojević, Dimitrijević: Impact of the Serbian Banking Regulatory Framework...

Masschelein, N. (2007). Monitoring pro-cyclicality under the capital requirements directive: Preliminary concepts for developing a framework. National Bank of Belgium. Working Paper no. 120.

Milojević, N. (2011). Efekti primene Bazelskih standarda u Srbiji. Beograd: Univerzitet Edukons i Čugura print.

Milojević, N. (2011). Perspektive promene zahteva za kapitalom banaka usled primene Bazelskih standarda. Poslovna ekonomija, 2(9), 171-191.

Izveštaj za treće tromesečje 2011. godine, Kontrola poslovanja banaka (2011) Retrieved from http://www.nbs.rs/internet/cirilica/55/55 4/index.html

National Bank of Serbia Retrieved from http://www.nbs.rs

Odluka o usklađivanju bruto plasmana odobrenih stanovništvu sa osnovnim kapitalom banaka. SI. glasnik RS, br. 39/2006, 49/2006, 64/2006, 31/2007, 77/2007, 35/2008, $65 / 2008$ i $12 / 2009$.

Savić, L., \& Bošković, G. (2011). Uticaj svetske ekonomske krize na razvoj Srpske industrije. Industrija, 39(4), 87-106. Retrieved from http://scindeks.ceon.rs/article.aspx?artid=0350-03731104087S0

Statistical Office of Republic of Serbia Retrieved from http://webrzs.stat.gov.rs/axd/index.php 